\title{
ДИПЛОМАТИЯ
}

С.С. Хизриева

DOI: 10.7256/2305-560X.2013.3.8879

\section{ИНФОРМАЦИОННОЕ ОБЕСПЕЧЕНИЕ ВНЕШНЕЙ ПОЛИТИКИ БРАЗИЛИИ В ЕВРОСОЮЗЕ}

\begin{abstract}
Аннотация. Информационное обеспечение внешней политики - это обеспечение государства фактическими данными с учётом целевой аудитории (внутренней и внешней) с целью информирования, а также защиты и управление информацией, посредством каналов коммуникации. Информатизация Бразилии в начале ХХІ в. способствовала использованию технологий внешнеполитического коммуникационного менеджмента, таких как репутационный менеджмент, общественная дипломатия, межкультурные коммуникации для налаживания внешнеполитических отношений со странами ЕС. Создание информационно оснащённых правительственных и посольских сайтов Бразилии, рассчитанных на работу с зарубежной аудиторией EC, способствовала развитию двухсторонних контактов между двумя регионами, начиная от экономических и политических проектов и заканчивая научно-культурным сотрудничеством. Улучшив качество правительственных и посольских сайтов, информационных агентств, вещающих на зарубежную аудиторию, Бразилии удалось не только поправить отрицательную репутацию, которая была у нее до 2007 г., но и значительно повысить уровень общественной дипломатии посредством сетевого общения с европейской аудиторией.

Ключевые слова: дипломатия, внешняя политика, информационное обеспечение, Бразилия, ЕС, стратегическое партнёрство, двухсторонние отношения, информационные агентства, посольские сайты, межкультурная коммуникация, блоги.
\end{abstract}

И нформационное обеспечение внешней политики - это обеспечение государства фактическими данными с учётом целевой аудитории (внутренней и внешней) с целью информирования, а также защиты и управления информацией, посредством каналов коммуникации.

Если говорить о внешней целевой аудиторией, то информационное обеспечение направлено на удовлетворение информационных потребностей общества с учётом характера конфиденциальности. Если дело касается внутренней целевой аудитории (президент, руководство, топменеджмент), то характер и содержание информационного обеспечения кардинально меняется, т.е. это информация поступает как с открытых источников, так и с закрытых (внутренние ресурсы государственного аппарата), а также информация с информационноаналитического отдела.

С начала 2000-х гг. происходила смена власти от традиционных до новых участников и в международных отношениях наметился процесс перенастройки, началась эпоха многополярности и, признавая новые обстоятельства, ЕС запустил ряд предложений присоединиться по соглашению о стратегическом партнёрстве, «привлекательным» партнёрам 27 государствам - членам Союза в фор- ме отношений для достижения общих интересов и цели.

Стоит отметить, что на активизацию международного сотрудничества повлиял приход к власти Лулы да Силвы в 2003 г. После прихода Лулы и начала его позитивных преобразований как внутри страны, так и во внешней политике Бразилии, именно в этот период ЕС начинает активизировать двусторонние отношения с Бразилией.

В январе 2004 г. Бразилия и ЕС подписывают Двустороннее соглашение о научно-техническом сотрудничестве. В 2005 г. начинаются визиты на высшем уровне.

В 2007 г. Бразилия стала шестым государством, которая стала для ЕС Стратегическим партнёром № 1. Впервые ЕС в официальных документах отмечает, что «пришло время взглянуть на Бразилию в качестве стратегического партнера, а также как на крупного латиноамериканского экономического актора и регионального лидера». Для того, чтобы понять, насколько успешно проводится информационное обеспечение политики Бразилии в ЕС, необходимопровести контент анализ посольств Бразилии в ЕС и официального сайта европейской комиссии: 


\section{Международные отношения International Relations}

\section{Контент анализ официального сайта Европейской комиссии выявил:}

\begin{tabular}{|c|c|c|c|c|}
\hline Слово & $\begin{array}{c}\text { Количество } \\
\text { упоминания }\end{array}$ & $\begin{array}{c}\text { Количество } \\
\text { нейтральных } \\
\text { упоминаний }\end{array}$ & $\begin{array}{c}\text { Количество } \\
\text { упоминаний в } \\
\text { положительном } \\
\text { контексте }\end{array}$ & $\begin{array}{c}\text { Количество } \\
\text { упоминаний } \\
\text { в негативном } \\
\text { контексте }\end{array}$ \\
\hline «Бразилия» & 33 раза & 15 & 17 & 1 \\
\hline «EC» & 19 раз & 8 & 11 & 0 \\
\hline «США» & 14 раз & 7 & 3 & 4 \\
\hline
\end{tabular}

На официальном сайте Европейской комиссии в разделе посвящённом Бразилии, размещена информация, касающаяся торговли ЕС с Бразилией.

Таким образом, можно сделать вывод, что в целом Бразилия упоминается с положительной стороны, но судя по тесту чувствуется конкуренция EC с США. В тексте можно выделить лёгкий негативный оттенок в сторону Бразилии, когда речь заходит о её торговых связях с США, в случае упоминания США в негативном контексте происходит через сравнение c EC по наименованию экспорта у Бразилии, показывая примитивные экономические связи США с Бразилией. ЕС на данном сайте не имеет отрицательного контекста, количество положительного контекста превалирует над нейтральными упоминаниями, что вполне предсказуемо. В целом можно отметить, что данный сайт носит сугубо справочную информацию, текст изложен без особой эмоциональной окраски и достаточно сжато.

Деятельность правительства Бразилии успешна в ряде направлений и она коммутирует объективно в сознании целевых групп и зарубежных в том числе, определённые положительные моменты, но слова и образы призваны усилить это.

За информационно - коммуникационное обеспечение Бразилии в ЕС в первую очередь отвечают официальные посольские сайты.

Именно сайты посольств являются одним из проводников общественной дипломатии Бразилии в ЕС.

Проведенный анализ сайтов посольств Бразилии в ЕС позволяет сделать вывод о том, что деятельность посольств Бразилии в ЕС заключается:

- в расширении межкультурной коммуникации между двумя регионами;

- развитии торгово-экономических и политических взаимоотношений между двумя регионами;

- $\quad$ корректировкой имиджа Бразилии в EC;

- в распространении бразильских ценностей в EC;
- $\quad$ в поддержке стратегического партнерства между регионами.

Так, сайты посольств Бразилии, в отличие от других сайтов посольств стран Латинской Америки, одинаковы по своей структуре и оформлению. Кроме того, можно отметить, что все сайты содержат подробнейшую информацию о двухсторонних отношениях между Бразилией и той или иной страной ЕС.

Говоря об усиливающемся стратегическом партнерстве между двумя регионами нельзя не отметить, что сайты посольств Бразилии в ЕС разработаны в соответствии с последними достижениями в области информационных интернет-технологий и по своей оснащённости и информации не уступают правительственным сайтам США, ЕС, Китая, Индии и заметно опережают в этом другие страны латиноамериканского региона.

Важным достижением в области информационно-коммуникационной международной политики Бразилии в ЕС является раздел на сайте посвященный общественной дипломатии Бразилии в мире, который свидетельствует об относительной прозрачности политических позиций Бразилии и свидетельствует о высоком демократическом развитии этой страны. Эта позиция Бразилии без сомнения должна оказать влияние на формирование положительного имиджа у ее стратегических партнеров.

Говоря о межкультурной коммуникации Бразилии в ЕС следует также с положительной стороны отметить работу культурных отделов посольств Бразилии в ЕC.

Так, начиная с 2003 г. между Бразилией и странами EC в значительной степени возросло число культурных и образовательных программ. Здесь следует отметить, что Бразилия среди стран Латинской Америки занимает лидирующее положение по числу культурно-образовательных мероприятий ежегодно проводимых в странах EC. 
Каждый месяц в разделах сайта по культуре публикуется ежемесячная культурная программа, проводимая при активном участии посольства Бразилии в той или иной стране ЕС. Проведенный анализ ежемесячных культурных программ Бразилии, в странах ЕС начиная с 2004 г. показал, что приблизительно 5 дней в неделю посольство Бразилии совместно с культурными и научными институтами той или иной страны ЕС проводят музыкальные фестивали, художественные выставки, показ фильмов, научные семинары и др.

Кроме того в результате совместной работы Бразилии и стран ЕС в области культурного сотрудничества были созданы европейско-бразильские СМИ, что в первую очередь является заслугой информационно-коммуникационной политики проводимой Бразилией в странах ЕС. Ярким примером может послужить создание совместного франкобразильского международного радиовещания.

Другим примером удачной пропаганды культурных ценностей, которую проводит Бразилия и ее латиноамериканские партнеры может послужить французский культурный сайт Amelatine L'Amgrique latine en France на котором располагается подробная информация обо всех странах латиноамериканского региона, а также об основных латиноамериканских культурных мероприятиях проходящих во Франции, организованных посольствами этих стран. В итоге за последние несколько лет значительно увеличилось количество поездок французских студентов в Бразилию и в другие стра- ны Латинской Америки с целью культурно-образовательного обмена. Огромная работа по продвижению латиноамериканских культурных ценностей ведется европейской молодежью в социальных сетях. Так, в Facebook, skyrock, myspace имеются самостоятельные европейские блоги созданные для поддержки европейско-бразильского стратегического сотрудничества.

Здесь следует отметить, что к качестве основных методов продвижения своих политических интересов, можно выделить культурные мероприятия, посвященные историческому Бразилии, которые способствуют установлению тесных контактов между левым крылом европейской политической элиты и представителями левого крыла бразильской политической элиты, рассчитанных на широкое участие в них европейской и латиноамериканской молодежи.

Создание информационно оснащённых правительственных и посольских сайтов Бразилии, рассчитанных на работу с зарубежной аудиторией ЕС, способствовала развитию двухсторонних контактов между двумя регионами начиная от экономических и политических проектов и заканчивая научно-культурным сотрудничеством.

Вовлечение широких слоев европейского населения, в особенности молодежных движений, в создание блоговых культурных объединений и сайтов также свидетельствует об эффективности информационно-коммуникационной политики Бразилии в отношениях с EC. 